\section{Eggs Incubated in Sub-Zero Weather}

By P. Beckie, Bladworth, Sask.

On April 17th, I was out on a hike with my younger brothers and our dog. As we were scouting from slough to slough, I kept a watch for Horned Owl nests. We found one, a half mile from home, on April 8th. It contained one egg. This pair of owls abandoned the nest after we looked in it. The weather on the 17 th was quite mild but overcast. Mallards and Pintails were calling here and there as they looked over nesting sites. About one and a half miles from home I noticed an old hawk nest that I remembered from past years. From a distance I noticed the head of an owl above the nest edge. As I walked closer, the partner who had been perching nearby flew to a neighboring thicket. As the weather this spring was very harsh for incubating birds, I was interested in seeing how these birds were making out. I climbed the tree, after wading through a foot of water. There were three downy young in the nes.t, with the oldest sprouting his first feathers. There was also the hind quarters of a rat in the nest.

The weather, during the last week in March, was as cold as $27^{\circ}$ below zero. But here were three young owls - one about 6 inches long, the next about 4 to 5 inches long, and the smallest about 3 inches in length. The oldest must have been at least 2 weeks old; then there couldn't be any doubt that the parents were sitting on the eggs during that week of five stormy sub-zero days.

It surely is an admirable feat.

\section{Christmas Trees}

By Marjorie F. Mann, Piapot, Sask.

Have you ever seen a living moving Xmas tree? Early one morning, during Christmas week, while looking out the kitchen window towards the garden, we saw a flock of fifty or more Bohemian Waxwings light on a Cotoneaster bush feasting on the dried berries and flying from there to a spruce tree nearby. Both bush and tree were literally alive.
The birds only stayed a few minutes and were gone, leaving a mind picture never to be forgotten.

There must be something special about the Cotoneaster berries. During the heavy snows of Spring, 1954, the Robins refused all the other food and scratched down under the snow for the berries. The rabbits have a path to the bushes throughout the winter, not bothering the bark much, but eating the berries.

\section{The Vanishing "Prairie Chicken"}

By Wm. E. Jasper, Struan, Sask.

It used to be that when one would go out to the field, or to the bluffs to cut firewood, some of these fine birds would be seen. One winter about thirty years ago, when there was quite a depth of snow, about two hundred of these birds would come up into our yard to feed at the stacks. But not so now! Some winters I do not see any for a month or six weeks at a time. This year it was February 1st before I saw any, then I saw six. There were no more until March 24th, when nine flew up from the side of the road, as we were on the way to town.

No doubt there are many factors contributing to the disappearance of the Sharp-tailed Grouse.

1st: Many of the small bluffs, around which they used to nest and find much of their food, have been cut out.

2nd: Since the Magpies moved in during the early twenties, they have taken a heavy toll of our game birds. The fact that they like the same kind of small-bluff-country as the grouse enables them to search out and destroy both their eggs and young.

3rd: There is no doubt that in some localities the Sharp-tailed Grouse receive competition for food from the European Grey Partridge that moved here in 1924.

The cooperation of all nature lovers can do much to increase the numbers in the next few years. The Blue Jay can do much to arouse public interest in the preservation of the Sharp-tailed Grouse. 